An ESRC Research Group

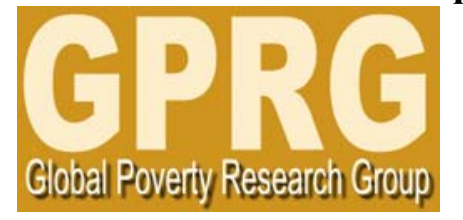

\title{
Have NGOs 'Made a Difference?' \\ From Manchester to Birmingham with an Elephant in the Room
}

\section{GPRG-WPS-028}

\section{Michael Edwards}

\section{Global Poverty Research Group}

Website: http://www.gprg.org/

The support of the Economic and Social Research Council (ESRC) is gratefully acknowledged. The work was part of the programme of the ESRC Global Poverty Research Group. 


\title{
Have NGOs 'Made a Difference?' \\ From Manchester to Birmingham with an Elephant in the Room
}

\author{
Michael Edwards* \\ Ford Foundation, USA.
}

In 1991, David Hulme and I found ourselves in a bar at the University of Hull enjoying a post-conference beer. The conversation turned to a mutual interest of ours - the role and impact of NGOs in development - and after a few more pints we hit on the idea that eventually became the first 'Manchester Conference' on the theme of 'scaling-up', later to be summarized in a book called 'Making a Difference: NGOs and Development in a Changing World' (Edwards and Hulme, 1992). Fifteen years on, the NGO universe has been substantially transformed, with rates of growth in scale and profile that once would have been unthinkable. Yet still the nagging questions remain. Despite the increasing size and sophistication of the development NGO sector, have NGOs really 'made a difference' in the ways the first Manchester Conference intended, or have the reforms that animated the NGO community during the 1990s now run out of steam?

In this paper I try to answer these questions in two ways. First, through a retrospective of the Manchester conferences - what they taught us, what influence they had, and how NGOs have changed. And second, by picking out a couple of especially important challenges in development terms and assessing whether NGOs 'stood up to be counted', so to speak, and did their best in addressing them. These two approaches suggest somewhat different conclusions, which will bring me to the 'elephant in the room' of my title.

It is obvious that making judgments about a universe as diverse as development NGOs is replete with dangers of over-generalization, and difficulties of attribution, measurement, context, and timing. I suspect my remarks may be particularly relevant for International NGOs and to larger intermediary NGOs based in the South. So with these caveats in mind, what does the last decade and a half tell us about the role and impact of NGOs in development?

\section{The Manchester Conferences: a short retrospective}

As Table One shows, the theme of the first Manchester Conference in 1992 was 'Scalingup NGO impact on development.' 'How can NGOs progress from improving local situations on a small scale to influencing the wider systems that create and reinforce

\footnotetext{
* Keynote Speech at the GPRG sponsored conference on Reclaiming Development? Assessing the Contribution of Non-Governmental Organizations to Development Alternatives, Institute for Development Policy and Management, University of Manchester, 27-29 June 2005. The views expressed in this paper are the author's own personal views and should not be taken to reflect the position of the Ford Foundation. (C) Michael Edwards 2005.
} 
poverty?' (Edwards and Hulme, 1992, p.7). The conference concluded that were different strategies suited to different circumstances, specifically: 1) working with government 2) operational expansion 3) lobbying and advocacy 4) and networking and 'self-spreading' local initiatives.

All of these strategies have costs and benefits, but the implicit bias of the conference organizers, and most of the participants, lay towards institutional development and advocacy as the most effective and least costly forms of scaling-up, what Alan Fowler later called the 'onion-skin' strategy for NGOs - a solid core of concrete practice (either direct project implementation or support to other organizations and their work), surrounded by successive and inter-related layers of research and evaluation, advocacy and campaigning, and public education. To varying extents, this strategy has become standard practice for development NGOs in the intervening years.

Buried away at the end of 'Making a Difference' was the following statement: 'The degree to which a strategy or mix of strategies compromises the logic by which legitimacy is claimed provides a useful test of whether organizational self-interest is subordinating mission' (Edwards and Hulme, 1992, p 213). For reasons that I will come back to later in my paper, that has turned out to be a prescient conclusion.

Fast forward to the second Manchester Conference in 1994, in a context in which NGOs had begun to 'scale-up' rapidly in an environment in which they were seen as important vehicles to deliver the political and economic objectives of the 'New Policy Agenda' that was being adopted by official donor agencies at the time - deeper democratization through the growth of 'civil society', and more cost-effective delivery of developmentrelated services such as micro-credit and community-driven development. As a result, many NGO budgets were financed increasingly by government aid, raising critical questions about performance, accountability, and relations with funding sources: The key question for that conference was as follows: 'will NGOs be co-opted into the 'New Policy Agenda' as the favored child, or magic bullet for development?' (Edwards and Hulme, 1995, p.7). And if so, what would that do to NGO mission and relationships? Will they, as another of the conference books put it, become 'too close to the powerful, and too far from the powerless' (Hulme and Edwards, 1997, p.275)?

At the time, our conclusion was that such problems were not inevitable. Whether they arise depends on the quality of the relationships that develop between actors, and on how each NGO uses its 'room-to-maneuver' to control for the costs of growth and donordependence. Therefore, negotiation between stakeholders is vital, requiring innovation in performance-assessment, accountability mechanisms, and relations with funding agencies. 'The developmental impact of NGOs,' we concluded, 'their capacity to attract support, and their legitimacy as actors in development, will rest much more clearly on their ability to demonstrate that they can perform effectively and are accountable for their actions. It is none too soon for NGOs to put their house in order' (Edwards and Hulme, 1995, pp.227-8). 
Since 1994 there have been some important innovations in this respect, like the Humanitarian Accountability Project; the rise of self-certification and accreditation schemes, seals of approval and codes of conduct among child sponsorship agencies and other NGOs; the development of formal compacts between government and the nonprofit sector in the UK, Canada and elsewhere; the Global Accountability Project in London; ActionAid's ALNAP system; and simple but powerful things like publicizing the financial accounts of an NGO on public bulletin boards that are being encouraged by MANGO and other organizations (Jordan and van Tuijl, forthcoming).

In retrospect however, NGOs did not heed this call with sufficient attention, and are now suffering from it in a climate in which, unlike ten years ago, weaknesses in NGO accountability are being used as cover for an attack on political grounds against voices that certain interests wish to silence. Examples of such attacks include the NGO Watch project at the American Enterprise Institute, the Rushford Report in Washington DC, and NGO Monitor in Jerusalem. Stronger NGO accountability mechanisms won't do away with politically motivated attacks like these, but they would surely help to expose them for what they are.

In 1999, the Third NGO Conference took place in Birmingham, framed by a rapidly changing global context that posed some deeper questions about NGO roles, relationships, capacities and accountabilities. 'Adapt or die' was the subtext of that meeting, whose organizers highlighted three key sets of changes:

First, globalization reshapes patterns of poverty, inequality and insecurity, calling for greater global integration of NGO strategies and more 'development work' of different kinds in the North.

Second, 'complex political emergencies' reshape patterns of humanitarian action, implying more difficult choices for NGOs about intervention and the need to re-assert their independence from government interests, and:

Third, a move from foreign aid as the key driver of international cooperation to a focus on rules, standards and support for those who are most vulnerable to the negative effects of global change implies greater NGO involvement in the processes and institutions of global governance, both formal and informal (Edwards et al, 1999, p2).

The thrust of these changes is clearly visible in the titles of the books that emerged from the Birmingham conference - 'NGO Futures: Beyond Aid' (Fowler, 2000), 'New Roles and Relevance' (Lewis and Wallace, 2000), and 'Global Citizen Action' (Edwards and Gaventa, 2001) - holding out the promise of transnational organizing among equals for systemic change as opposed to a secondary role shaped by the continued asymmetries of the foreign aid world.

This changing context, we believed, gave rise to four key challenges resulting from the evolution of a more political role for development NGOs in emerging systems of global governance, debate and decision making: 
1) How to mobilize a genuinely inclusive civil society at all levels of the world system, as opposed to a thin layer of elite NGOs operating internationally.

2) How to hold other (more powerful) organizations accountable for their actions and ensure that they respond to social and environmental needs - something that implicitly demanded reforms in NGO accountability too.

3) How to ensure that international regimes are implemented effectively and to the benefit of poor people and poor countries (getting to grips with 'democratic deficits' in global institutions and protecting 'policy space' for Southern countries to embark on their own development strategies), and:

4) How to ensure that gains at the global level are translated into concrete benefits at the grassroots (translating abstract commitments made in international conferences into actions that actually enforce rules and regulations on the ground: Edwards et al 1999, p10).

NGOs, we concluded, must move from 'development as delivery to development as leverage,' and this would require the development of more equal relationships with other civic actors, especially in the South, new capacities (like bridging and mediation), and stronger downward or horizontal accountability mechanisms.

Since 1999 there have certainly been some examples of innovations like these, like the 'Make Poverty History Campaign' in the UK (which has developed stronger coordination mechanisms among development and non-development NGOs, and other organizations in UK civil society), and the development of much more sophisticated advocacy campaigns on aid, debt and trade.

Now, if one believes that there is a credible chain of logic linking these three conferences, their outputs, and those of other similar efforts that were ongoing during the same period, with the emergence of a more thoughtful and professional development NGO sector; and going one stage further, linking the emergence of that sector with at least the possibility of a greater aggregate impact on development, then one can begin to answer the question posed by this volume in the affirmative, breaking down those answers by country context, type of organization, type of impact, longevity, sector, issue and so on in the ways that other papers try to do.

I think one would have to argue an extreme version of the counterfactual to say otherwise - in other words, to claim that the world would be a better place without the rise of development NGOs, however patchy their impact may have been, especially given the huge and complex challenges that face all NGOs in their work today. Perhaps I am not setting the bar very high in making this point, but in critiques of NGOs it is often forgotten. There has been a positive change in the distribution of opportunities to participate in development debates and in democracy more broadly, and in the capacities and connections required by NGOs to play their roles effectively, even if global trends in 
poverty and power relations, inequality, environmental degradation and violence are not all heading in a positive direction.

In other words, some of the preconditions, or foundations, for progress are being laid, brick by brick, organization by organization, community by community, vote by vote. If one believes that democratic theory works, then over time, more transparency, greater accountability, and stronger capacities for monitoring will feed through into deeper changes in systems and structures. Civil society may yet fulfill Kofi Annan's prediction as the 'new superpower' - a statement that was largely rhetorical but contained at least a grain of truth. And as context for that conclusion, think back thirteen years to the first Manchester Conference when NGOs were still something of a backwater in international affairs. No one could say the same thing today.

\section{Where we were wrong, and why it is important}

So, so far, so good. There was one major area, however, in which the analysis of previous conferences was seriously awry, and it has some significant consequences for the question of NGO impact in the future. This was the prediction that foreign aid would continue to decline and be replaced by a different, healthier and more effective system of international cooperation in which the drivers of development and change would no longer be based around North-South transfers and foreign intervention.

In fact, as one can see from Figure One, the clear decline in real aid flows that can be observed between 1992 to 1999 - exactly coinciding with the NGO Conferences - turns out to have been an atypical period in recent history. Backed by a growing coalition of celebrities, charities, politicians, journalists and academics, we are firmly back in a period of rising real aid flows, up to around $\$ 78$ billion in 2004, set to grow still further, and perhaps even reaching the promised land of $\$ 150-\$ 200$ billion a year estimated to be required to meet the United Nations Millennium Development Goals. The critical literature on aid effectiveness, the importance of institutions, and the primacy of politics that was developed during the 1990s has largely been marginalized from the current discourse (Edwards, 2004b). From Jeffrey Sachs to Bob Geldof, the new orthodoxy asserts that more money will solve Africa's problems, and, if we add in an American twist, make the world safe from terrorism too.

Of course, in 1999 no-one could have predicted some of the key reasons behind this reverse - principally the events of 9/11 and the ensuing 'war on terrorism', or the recent catastrophic Tsunami in Asia - but previous conferences were also guilty of confusing normative and empirical arguments. Much of the discussion at the Birmingham Conference was driven by what the organizers and participants wanted to see happen in the future, not necessarily by a hard-nosed analysis of likely trends and opportunities.

Why is this important for the rest of my argument? The reason is that the perseverance of the traditional aid paradigm, even in its modified version of Millennium Challenge Accounts, Poverty Reduction Strategy Papers, International Finance Facilities and the rest of the current paraphernalia of aid reform, makes any kind of quantum leap in NGO 
impact much more difficult to achieve because it weakens the incentives for deep innovation by providing a continued 'security blanket' for current practice. Of course, one can read this as a much more positive story, particularly when calls for aid are coupled with serious action on debt relief and trade justice. And I don't mean to imply that investment in developing countries is irrelevant - simply that is difficult to detach the dysfunctional aspects of the traditional aid paradigm from the injection of ever-larger amounts of money by powerful national interests into societies with weak institutions and fragile systems of accountability. To explain what I mean, let me move to the second way in which I've chosen to answer the questions I posed at the beginning of my argument.

\section{The 'Larry Summers Test'}

Recently, I attended a dinner at which the keynote speaker was Larry Summers, the evercontroversial President of Harvard University. After his speech was over, one brave member of the audience - a leading Arab academic - asked him point blank whether he thought that America 'has been a force for good in the world.' His answer was unconvincing, but interesting, since he said that it would be impossible to give a sensible answer to that question in any general sense. There are too many 'ifs, buts and maybes', and too many variations of detail, context and circumstance. However, he went on to say, one can ask whether America 'did the right thing' at those few moments in history when a certain course of action was unquestionably important - such as intervention in World War One, World War Two, and the Cold War. And in those cases, the answer was unequivocally 'yes.'

Now, of course one can dispute Summers' conclusion, but I think the way in which he repositioned the question is useful in relation to the topic of development NGOs and their impact. Instead of trying to generalize across the huge diversity of the NGO universe, we can ask ourselves whether NGOs 'did the right thing' on the really big issues of our times.

On the positive side of the balance sheet, I think development NGOs have helped to do the following, albeit with limited practical results thus far:

- Changed the terms of the debate on globalization, leading to the emergence of a new orthodoxy about the need to manage the downside of this process, level the playing field, and expand 'policy space' for developing countries.

- Cemented an intellectual commitment to participation and human rights as basic principles of development and development assistance, and:

- Kept the spotlight on the need for reforms in international institutions and global governance on issues such as unfair terms of trade and investment, global warming, Africa, and the kind of warped humanitarian intervention represented by the war in Iraq 
On the other hand, there is a less positive side to this story when one looks beyond the short-term gains that have made in development discourse to grapple with the underlying goals that NGOs were set up to pursue. In my view development NGOs have not 'stood up to be counted' sufficiently on the following crucial questions:

They have not been very innovative in finding ways to lever deep changes in the systems and structures that perpetuate poverty and the abuse of human rights, despite the recent boom in Corporate Social Responsibility and public-private partnerships. The 'onion', to go back to Alan Fowler's phrase, is still incomplete, made up by layers of fairly conventional development projects and advocacy work.

For example, development NGOs have not changed power relations on anything like the necessary scale in the crucial areas of class, gender and race. They have not faced up to the challenges of internal change - changes in personal attitudes, values and behavior - in any significant way. They have not established strong connections with social movements that are more embedded in the political processes that are essential to sustained change. They have not gotten to grips with the rise of religion as one of the most powerful forces for change in the world today, increasingly expressed in fundamentalism and demanding large-scale action to build bridges between pluralists in different religious traditions.

Equally important, development NGOs have not innovated in any significant sense in the form and nature of their organizational relationships. For example, little concrete attention is paid to downward accountability or the importance of generating diverse, local sources of funds for so-called 'partners' in the South (a weakness that underpins many other problems including legitimacy and political threats to organizations perceived as 'pawns of foreign interests'). They have internalized functions that should have been distributed across other organizations - local fundraising by international NGOs inside developing countries (or 'markets' to use a telling common phrase) provides a good example, and there are others - franchising global brands instead of supporting authentic expressions of indigenous civil society, and crowding out Southern participation in knowledge creation and advocacy in order to increase their own voice and profile, as if the only people with anything useful to say about world development were Oxfam and a handful of others.

Of course, there are exceptions to all of these generalizations. I would single out Action Aid for the changes it has made; and on a smaller scale I was struck by the Institute for Agriculture and Trade Policy's decision to transfer spaces on the NGO delegation to the Cancun trade talks from Northern NGOs to groups from the South in 2004. But these examples tend to get noticed because they are exceptions that prove the rule. The rules of the international NGO world themselves seem to stay the same. Does anyone believe that development NGOs still aim to 'work themselves out of a job', that old NGO mantra? Maybe it was never true, but there isn't much evidence to suggest that it is taken seriously today. Let's face it - NGOs are a major growth industry, back in the 'comfort zone', and set to continue along that path. There has been little real transfer of roles or capacity in either 'delivery' or 'leverage'. It's almost as though they have taken the entire 'onion' and swallowed it whole! 
NGOs may give a nod in the direction of 'leveling the playing field', diversifying NGO representation in the international arena, empowering marginalized voices, building the capacity of actors in the South for independent action, helping them to sustain themselves through indigenous resources, 'handing over the stick', becoming more accountable to beneficiaries and so on, but in practical terms the 'institutional imperatives' of growth and market share still dominate the 'developmental imperatives' of individual, organizational and social transformation (see Table Two). And - returning to the quotation I cited from 'Making a Difference' earlier in this paper - this failure places an important, continuing question mark against the legitimacy of development NGOs and their role in the contemporary world.

It is these failings, I believe, that stand in the way of increasing NGO impact in the future, and it is these failings that represent the 'elephant in the room' of my title. We don't want to recognize the beast, but we know it's there. And while it remains in the room - a hulking, largely silent presence - NGOs will never achieve the impact they say they want to achieve, because their leverage over the drivers of long-term change will continue to be weak.

One can read this story under the conventional rubric of institutional inertia, defensiveness and the difficulties of raising money for new and unfamiliar roles. But I think something more fundamental is going on. Underlying this situation is a much broader struggle between two visions of the future - one that I call 'international development,' and the other 'global civil society', for want of a better phrase.

The 'international development' vision is predicated on continued North-South transfers of resources and ideas as its centerpiece, temporarily under the umbrella of US hegemony and its drive to engineer terrorism out of the world, if necessary by refashioning whole societies in the image of liberal, free-market democracy. This vision requires the expansion of traditional NGO roles in humanitarian assistance, the provision of social safety-nets, and 'civil society building' (crudely translated as support to advocacy and service-delivery NGOs: Edwards 2004a). It. privileges technical solutions over politics, and the volume of resources over their use. The role of the North is to 'help' the lessfortunate and backward South; if possible, to 'save it' from drifting ever-further away from modernity as liberal market democracy (God forbid there is a viable alternative, like Islam); and if that fails, then at least to 'prevent it' from wreaking havoc on Northern societies. The 'war on terror', I would argue, reinforces and exacerbates the worst elements of the traditional foreign aid paradigm.

The 'Global Civil Society' vision, and here I'm exaggerating to make a point, takes its cue from cosmopolitan articulations of an international system in which international law trumps national interests, and countries - with increasingly direct involvement by their citizens - negotiate solutions to global problems through democratic principles, the fair sharing of burdens, respect for local context and autonomy, and a recognition of the genuinely interlocking nature of causes and effects in the contemporary world. This vision, to be successful, requires action in all of the areas in which I think development 
NGOs have been found wanting - leveling the playing field, empowering Southern voices, building constituencies for changes in global consumption and production patterns, and injecting real accountability into the system, including personal accountability for the choices that NGOs make. The struggle for global civil society can't be separated from the struggle for personal change, since it those changes that underpin the difficult decision to hand over control, share power, and live a life that is consistent with our principles. In this vision our role is to act as 'critical friends' as I put it on the last page of 'Future Positive,' sharing in 'the loving but forceful encounters between equals who journey together towards the land of the true and the beautiful' (Edwards, 2004b, p.233).

Recent history can be read as a reversal in what the Birmingham NGO Conference predicted would be a steady, long-term transition from the 'international development' model to 'global civil society.' Led by the United States, we are seeing a retreat from the cosmopolitan vision and a return to culturally-bound fundamentalisms, the hegemony of the nation state, and the belief that the world can indeed be remade in the image of the dominant powers through foreign intervention - with Iraq as the paradigm case. That, at root, is why there are so many attacks today on the institutions, or even the idea, of global governance, the rise of non-state involvement and the threats it supposedly carries, the legitimacy of international law, and the transnational dimensions of democracy - as opposed to the domestic implantation of versions of democracy in other peoples' countries.

It is no accident that hostility to international NGOs forms a key plank of NeoConservative thinking in America today. 'Post-democratic challenges to American democratic sovereignty should be clearly defined and resisted', writes John Fonte of the Hudson Institute, one of the key think-tanks of Neo-Conservatism. "NGOs that consistently act as if they are strategic opponents of the democratic sovereignty of the American nation should be treated as such. They should not be supported or recognized at international conferences, nor permitted access to government officials.' (Fonte, 2004). 'NGOs should be at the top of every Conservative's watch list' says Elaine Chao, President Bush's Secretary of Labor. So, 'you have been warned.' No matter how much additional foreign aid gets pumped through the international system, NGOs are unlikely to get very far unless they recognize that there are much bigger issues at stake. This is nothing less than a battle for the soul of world politics, and NGOs need to decide which side they want to take. I was convinced in Birmingham in 1999, and I'm even more convinced today, that we need to break free from the aid paradigm in order to liberate ourselves to achieve the impact that we want.

\section{Conclusion}

To sum up, my case is that the return of foreign aid to favor provides a security blanket for NGOs who might otherwise have been forced to change their ways. There may, of course be more unforeseen events in the near future that, like 9/11, provide an external shock to the system large enough to interrupt current trends and initiate new directions or, as in this case, return us to old ways of doing business. This might happen to 
development NGOs, for example, if aid donors ever got serious about cutting intermediaries (national and international) out of the equation, but I don't think this is very likely.

Therefore, I see only incremental increases in impact - shown by the hatched line in Figure Two - unless NGOs can break out of the foreign aid box, as a few pioneers are already doing. As they have recognized, there is a much healthier framework for civic action available to us if we decide to choose it. In my view, the advances made by development NGOs throughout the 1990s - spurred on significantly but not exclusively by the Manchester Conferences - represented a much bigger leap in NGO strategy and potential impact, shown by the solid line in Figure Two. Dealing effectively with the 'elephant in the room' represents the next such quantum leap.

In conclusion, the question facing development NGOs today is the same question that faced participants in the first NGO Conference in Manchester in 1992, albeit framed in a somewhat different context. That question is less about what NGOs have achieved in the absolute sense, since they can never achieve enough, and more about how they can achieve more, however well they think they are doing. How satisfied are NGOs with their current performance? Do they wait until another $9 / 11$ hits the system and shakes them out of their complacency, or can they 'bite the bullet' and implement their own gradual reforms now?

Perhaps when the development NGO community meets again in Manchester in ten years time, there will be a different set of answers on the table.

\section{References}

Edwards, M. (1996), 'International Development NGOs: Legitimacy, Accountability, Regulation and Roles', in Meeting the Challenge of Change: the report of the Commission on the Future of the Voluntary Sector. London: Commission on the Future of the Voluntary Sector.

Edwards, M. (2004a), Civil Society. Cambridge: Polity Press.

Edwards, M. (2004b), Future Positive: International Cooperation in the $21^{\text {st }}$ Century. Revised Edition. London: Earthscan.

Edwards, M., and D. Hulme (eds.) (1992), Making a Difference: NGOs and Development in a Changing World. London: Earthscan.

Edwards, M., and D. Hulme (eds) (1995), Beyond the Magic Bullet: NGO Performance and Accountability in the Post Cold-War World. London: Earthscan and West Hartford: Kumarian Press. 
Edwards, M., and J. Gaventa (eds) (2001), Global Citizen Action. Boulder: Lynne Rienner and London: Earthscan.

Edwards, M., D. Hulme and T. Wallace (1999), 'NGOs in a Global Future: Marrying Local Delivery to World-wide Leverage', Public Administration and Development 19(2), 117-36.

Fonte, John (2004), 'Democracy's Trojan Horse', The National Interest, Summer, pp 117-127.

Fowler, A. (ed.) (2000), NGO Futures: Beyond Aid, Special Issue of Third World Quarterly

German, T. and Ewing, D. (eds) (2004), Reality of Aid 2004: An Independent Review of Poverty Reduction and Development Assistance. London: Action Aid/ ICVA/ Eurostep.

Hulme, D., and M. Edwards (eds) (1997), Too Close for Comfort? NGOs, States and Donors. Basingstoke: Macmillan and New York: St Martins Press.

Lewis, D. and T. Wallace (eds) (2000), New Roles and Relevance: Development NGOs and the Challenge of Change. West Hartford: Kumarian Press.

Jordan, L., and P. van Tuijl (eds), (forthcoming), New Frontiers in NGO Accountability. 
Table 1: The Manchester Conferences: A Summary.

\begin{tabular}{|c|c|c|c|}
\hline $\begin{array}{l}\text { Date and } \\
\text { Location }\end{array}$ & Theme(s) & Key Conclusions & Published Outputs \\
\hline $\begin{array}{l}\text { Manchester } \\
1992\end{array}$ & $\begin{array}{l}\begin{array}{l}\text { Scaling-up NGO impact on } \\
\text { development: }\end{array} \\
\text { 'How can NGOs progress from } \\
\text { improving local situations on a small } \\
\text { scale to influencing the wider systems } \\
\text { that create and reinforce poverty?' }\end{array}$ & $\begin{array}{l}\text { Different strategies suit different circumstances: } \\
\text { 1) Working with government 2) operational expansion 3) } \\
\text { lobbying and advocacy 4) networking and 'self-spreading' } \\
\text { local initiatives. } \\
\text { All have costs and benefits but implicit bias to institutional } \\
\text { development and advocacy to control for dangers (the } \\
\text { 'onion-skin' strategy): } \\
\text { 'The degree to which a strategy or mix of strategies } \\
\text { compromises the logic by which legitimacy is claimed } \\
\text { provides a useful test of whether organizational self-interest } \\
\text { is subordinating mission' }\end{array}$ & $\begin{array}{l}\text { Making a Difference: } \\
\text { NGOs and Development } \\
\text { in a Changing World. } \\
\text { Scaling-Up NGO Impact } \\
\text { on Development: } \\
\text { Learning from } \\
\text { Experience (DIP) }\end{array}$ \\
\hline $\begin{array}{l}\text { Manchester } \\
1994\end{array}$ & $\begin{array}{l}\text { NGO growth raises questions about } \\
\text { performance, accountability and } \\
\text { relations with funding sources: } \\
\text { 'Will NGOs be co-opted into the New } \\
\text { Policy Agenda as the favored child, or } \\
\text { magic bullet for development?' } \\
\text { If so, what does that do to NGO } \\
\text { mission and relationships - 'too close } \\
\text { to the powerful, too far from the } \\
\text { powerless?' }\end{array}$ & $\begin{array}{l}\text { Problems are not inevitable - they depend on the quality of } \\
\text { relationships between actors and how 'room-to-maneuver' } \\
\text { is exploited. } \\
\text { Therefore, negotiation between stake- holders is vital, } \\
\text { requiring innovation in performance assessment, } \\
\text { accountability mechanisms, and relations with funders. } \\
\text { 'The developmental impact of NGOs, their capacity to } \\
\text { attract support, and their legitimacy as actors in } \\
\text { development, will rest much more clearly on their ability to } \\
\text { demonstrate that they can perform effectively and are } \\
\text { accountable for their actions. It is none to soon for NGOs to } \\
\text { put their house in order.' }\end{array}$ & $\begin{array}{l}\text { Beyond the Magic } \\
\text { Bullet: } \\
\text { NGO Performance And } \\
\text { Accountability in the } \\
\text { Post Cold-War World (x } \\
\text { 2) } \\
\text { NGOs, States and } \\
\text { Donors: Too Close for } \\
\text { Comfort? (x 2) } \\
\text { Too Close For Comfort: } \\
\text { The Impact of Official } \\
\text { Aid on NGOs (WD) }\end{array}$ \\
\hline
\end{tabular}




\begin{tabular}{|c|c|c|c|}
\hline & & & $\begin{array}{l}\text { Policy Arena: New Roles } \\
\text { and Challenges for } \\
\text { NGOs (JID) }\end{array}$ \\
\hline $\begin{array}{l}\text { Birmingham } \\
1999\end{array}$ & $\begin{array}{l}\text { The changing global context poses } \\
\text { questions about NGO roles, } \\
\text { relationships, capacities and } \\
\text { accountabilities } \\
\text { 'Adapt or die!' Three key changes: } \\
\text { 1) globalization reshapes patterns of } \\
\text { poverty, inequality and insecurity } \\
\text { 2) 'complex political emergencies' } \\
\text { reshape patterns of humanitarian action } \\
\text { 3) the focus of international } \\
\text { co-operation is moving from a focus } \\
\text { on foreign aid to a focus on rules, } \\
\text { standards and supports for those most } \\
\text { vulnerable. } \\
\text { Hence, 'NGO Futures Beyond Aid', } \\
\text { 'New Roles and Relevance', and } \\
\text { 'Global Citizen Action' - transnational } \\
\text { organizing among equals for systemic } \\
\text { change cf North- } \\
\text { South transfers and interventions. }\end{array}$ & $\begin{array}{l}\text { This changing context gives rise to } 4 \text { challenges for NGOs: } \\
\text { 1) mobilizing a genuinely inclusive civil society at all } \\
\text { levels of the world system } \\
\text { 2) holding other organizations accountable for their actions } \\
\text { and ensuring they respond to social and environmental } \\
\text { needs } \\
\text { 3) ensuring that international regimes are implemented } \\
\text { effectively and to the benefit of poor countries } \\
\text { 4) ensuring that gains at the global level are translated into } \\
\text { concrete benefits at the grassroots. } \\
\text { NGOs must move from 'development as delivery to } \\
\text { development as leverage', or 'marry local development to } \\
\text { worldwide leverage' } \\
\text { This requires more equal relationships with other civic } \\
\text { actors, especially in the South, new capacities (e.g. bridging } \\
\text { and mediation), and stronger accountability mechanisms. }\end{array}$ & $\begin{array}{l}\text { NGOs in a Global } \\
\text { Future: Marrying Local } \\
\text { Delivery to Worldwide } \\
\text { Leverage (PAD) } \\
\text { New Roles and } \\
\text { Relevance: Development } \\
\text { NGOs and the Challenge } \\
\text { of Change } \\
\text { NGO Futures: Beyond } \\
\text { Aid (TWQ) } \\
\text { Global Citizen Action }\end{array}$ \\
\hline
\end{tabular}




\section{Figure 1}

The long term trend in ODA from DAC donors

in $\$$ millions real terms (2001 prices)

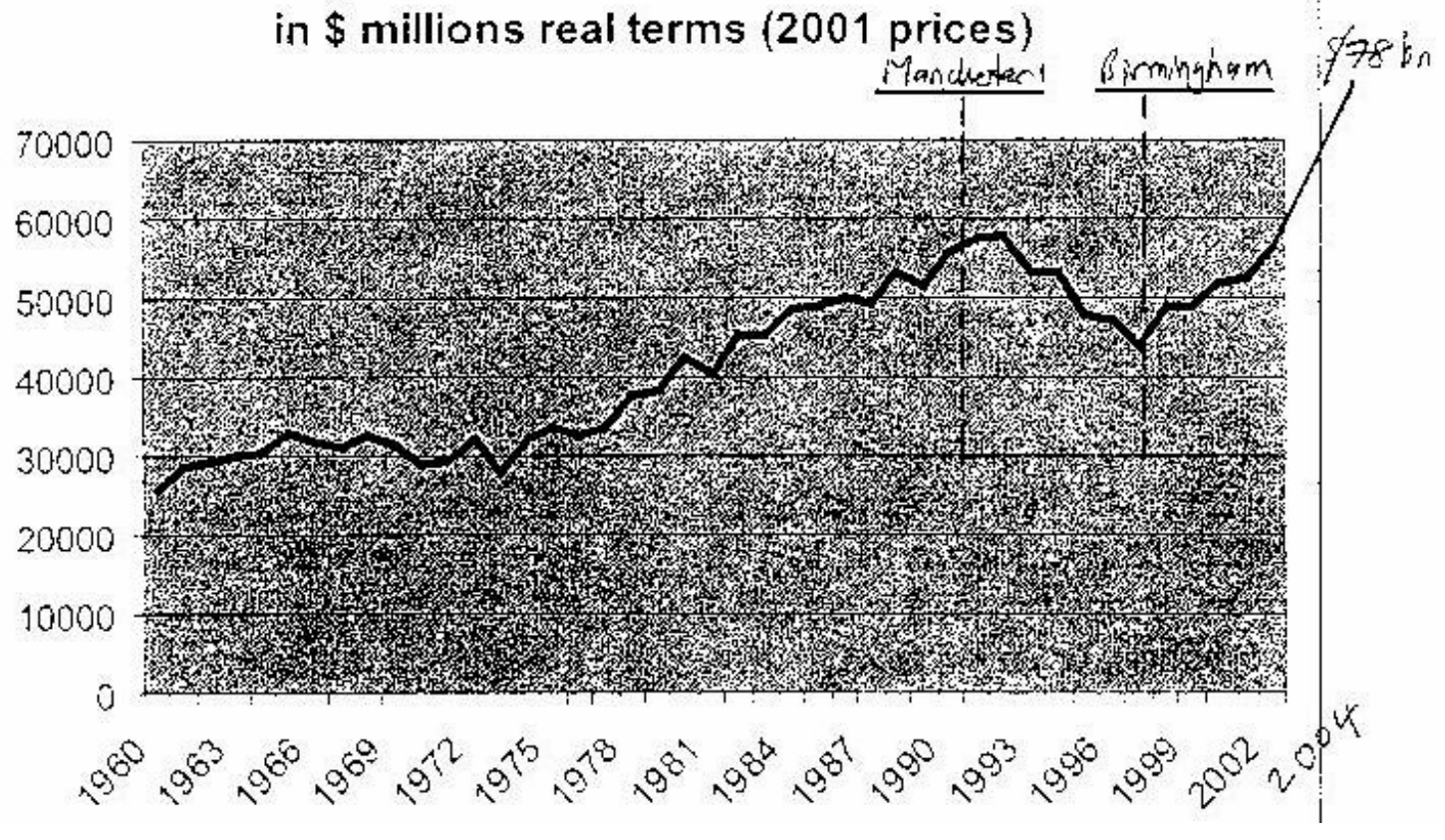

Source: German and Ewing (2004). 
Table 2: NGO Imperatives

\section{DEVELOPMENTAL IMPERATIVES}

Bottom line: empowering marginalized groups for independent action

Downplay the role of intermediary;

encourage marginalized groups to speak with their own voice

Democratic governance; less hierarchy; more reciprocity; a focus on stakeholders

Multiple accountability, honesty, learning from mistakes, transparency, sharing of

information

Maintain independence and flexibility; take risks

Address the causes of poverty; defend

values of service and solidarity

Long term goals drive decision making; programme criteria lead

Rooted in broader movements for change;

alliances with others; look outwards

Maximize resources at the 'sharp end'; cooperate to reduce overheads and transaction costs

Maintain focus on continuity, critical mass and distinctive competence

Source: Edwards (1996).

\section{INSTITUTIONAL IMPERATIVES}

Bottom line: size, income, profile, market share

Accentuate the role of intermediary; speak on behalf of marginalized groups

More hierarchy; less reciprocity; a focus on donors and recipients

Accountability upwards, secrecy, repeat mistakes, exaggerate successes and disguise failures

Increasing dependence on government funds; standardization; bureaucracy Deal with symptoms: internalize orthodoxies even when antithetical to mission

Short term interests drive decision making; marketing criteria lead Isolated from broader movements for change; incorporate others into your own structures; look inwards

Duplicate delivery mechanisms (e.g. separate field offices); resources consumed increasingly by fixed costs Opportunism - go where the funds are; increasing spread of activities and countries 
Figure 2: Trajectories of NGO Impact.

'The Elephant in the Room'

'Delivery to Leveraqe'

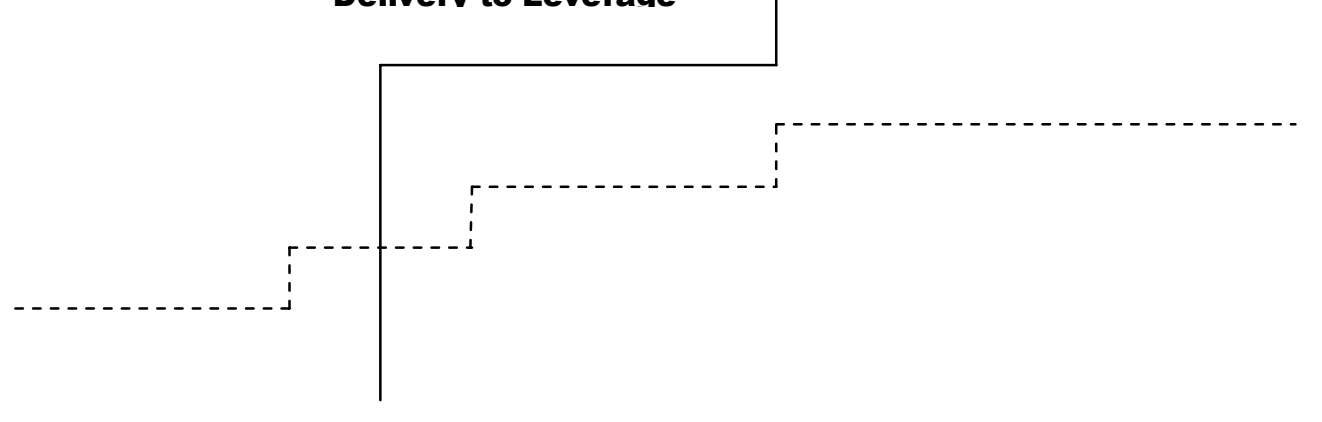

